\title{
COMPARATIVE EFFECTIVENESS OF ANIMAL MANURES ON SOIL CHEMICAL PROPERTIES, YIELD AND ROOT GROWTH OF AMARANTHUS (Amaranthus cruentus L.)
}

\author{
A. P. Maerere ${ }^{1 *}$ G. G. Kimbi ${ }^{2}$ and D. L. M. Nonga ${ }^{3}$ \\ ${ }^{1}$ Department of Crop Science and Production, \\ Sokoine University of Agriculture, P.O. Box 3005, Morogoro, Tanzania. \\ ${ }^{2}$ Institute of Continuing Education, \\ Sokoine University of Agriculture, P.O. Box 3044, Morogoro, Tanzania. \\ ${ }^{3}$ Department of Agriculture and Livestock Development, P.O. Box 26, Singida, Tanzania. \\ *E-mail: maerere@suanet.ac.tz
}

\begin{abstract}
Pot and field experiments were conducted to compare the effects of dairy cow, goat and poultry manures on soil available levels of $N$ and $P$ and amaranths yield and root growth. The three amendments were applied on Oxisols at 100, 150 and $170 \mathrm{~kg} \mathrm{~N} / \mathrm{ha}$ in a split plot design and replicated three times. Pot experiment lasted for one month whereas field experiment was conducted over three monthly crop cycles. Results of both experiments indicated that applications of the three manures significantly $(P<0.01)$ increased soil available levels of $N$ and $P$ shoot dry matter yield, taproot length and root dry weight. Comparison of the responses from the three manures revealed that for all the parameters evaluated the trend was; Poultry manure $>$ goat manure $>$ dairy cow manure. This was largely attributed to differences in total $N$, total $P, C / N$ and $C / P$ ratios of the amendments. Field experiment results revealed that responses were highest after the third crop harvest suggesting that mineralization of organic $N$ and $P$ increased with time. Based on fertilizer recommendations of $N$ and $P$ for Southern highlands of Tanzania and the highest rate used in this study $(170 \mathrm{~kg} \mathrm{~N} / \mathrm{ha})$, applications of 5.8 tons $/ \mathrm{ha}, 9.8$ tons/ha and 13.4 tons/ha of poultry, goat and dairy cow manure will suffice the requirement of $40 \mathrm{~kg} \mathrm{~N} / \mathrm{ha}$ and $20 \mathrm{~kg}$ P/ha recommended for most field crops.
\end{abstract}

\section{INTRODUCTION}

Sustainable crop production requires judicial use of inputs such as fertilizers. The use of inorganic fertilizers has drastically declined following the energy crisis, which has immensely affected most of the developing countries (Hauck, 1982). In Tanzania, reduced use of inorganic fertilizers has largely been aggravated by the removal of fertilizer subsidies by the government. This has resulted in low crop yields due to deteriorating land productivity.

Tanzania is however, endowed with a large number of livestock such as cattle, goats, sheep, pigs, donkeys and poultry. According to Kimbi et al. (1999) animal manure output in mainland Tanzania is about 14 million tons per year. If it is assumed that average $\mathrm{N}$ content of animal manure is $0.7 \%$ the total $\mathrm{N}$ from the manure is 94500 tons.
This is about four times the amount of nitrogenous fertilizers used in the country in 1980. Efficient use of animal manure could therefore alleviate the problem of declining land productivity in most parts of Tanzania.

Irrespective of the enormous manure production potential, very little amount of the available animal manure is being utilised for crop production. Kimbi et al. (1992) observed that in extensive livestock grazing systems only about $1 \%$ of farmers apply animal manure on land, indicating serious under utilisation of such resources. This is largely due to lack of scientific basis for advising farmers on aspects such as appropriate application rates, storage techniques and application methods (Gabriel, 1998). 
In view of the apparent decline in soil fertility, deliberate efforts are required to promote utilization of animal manure for crop production. Most studies on utilization of animal manure in Tanzania have largely focused on crop yield responses of field crops with very little effort to relate such responses with availability of nutrients. Efficient utilization of animal manure requires thorough understanding of the relationship between crop responses and availability of nutrients in the soil following animal manure application. Furthermore, there is also a need for comparing different types of animal manures under similar field conditions. This is important in coming up with indications on manure recommendations. The current study was therefore carried out in order to compare the effectiveness of poultry, goat and dairy cow manure on soil availability of $\mathrm{N}$ and $\mathrm{P}$, amaranthus (Amaranthus cruentus L.) yield, and root growth after the initial application of the manures. Amaranthus was chosen as the test crop due to its nutritional and economic importance in most parts of Tanzania. It is the most popular vegetable crop grown in most home gardens and is a fast growing annual crop requiring intensive application of fertilizers.

\section{MATERIALSAND METHODS}

The study was conducted at Sokoine University of Agriculture (SUA) located at $6^{\circ} 5^{\prime} \mathrm{S}$ and $37^{\circ} 38^{\prime} \mathrm{E}$ and $550 \mathrm{~m}$ a.s.l. during the $1997 / 98$ growing season. Soil samples from the top $0-20 \mathrm{~cm}$ were collected from the experimental site for laboratory analysis and pot experiment. The samples were randomly collected to represent the experimental area. The samples for pot experiment were composited, air dried, ground and sieved to pass through an $8 \mathrm{~mm}$ sieve. A small sub-sample was composited, air dried, ground and sieved to pass through a $2 \mathrm{~mm}$ sieve for physical and chemical characterization of the soil. The soil sample was analysed for soil texture, $\mathrm{pH}$, organic carbon, total $\mathrm{N}$, extractable $\mathrm{P}$, exchangeable levels of $\mathrm{Ca}, \mathrm{Mg}, \mathrm{Na}$ and $\mathrm{K}$, and cation exchange capacity. Soil texture was determined by the Bouyoucos hydrometer method (Juo, 1978). Soil pH was measured electrometrically in a 1:2.5 soil-water suspension (McLean, 1982). Organic carbon was determined by rapid dichromate oxidation method. Total nitrogen was determined by the Micro Kjeldahl method (Bremner and Malvaney, 1982), whereas extractable $P$ was determined by Bray 1 Method (Bray and Kurtz, 1945). Exchangeable levels of $\mathrm{Ca}, \mathrm{Mg}, \mathrm{K}$ and $\mathrm{Na}$ were determined by the atomic absorption spectrophotometer following the procedures outlined by Wilde et al. (1979). Cation exchange capacity was determined by the ammonium acetate saturation method (Thomas, 1982). The results of these analyses are summarised in Table 1.
TABLE 1. Some physico-chemical properties of soil used in this study

\begin{tabular}{|c|c|}
\hline Parameter & Value \\
\hline Sand $(\%)$ & 47 \\
\hline Silt (\%) & 22 \\
\hline Clay (\%) & 31 \\
\hline Textural Class & Sandy Clay Loam \\
\hline Total N (\%) & 0.154 \\
\hline \multicolumn{2}{|l|}{ Exchangeable bases } \\
\hline \multicolumn{2}{|l|}{$(\mathrm{Cmol}(+) / \mathbf{k g}$ soil $)$} \\
\hline $\mathrm{K}^{+}$ & 1.68 \\
\hline $\mathrm{Na}^{+}$ & 0.54 \\
\hline $\mathrm{Ca}^{++}$ & 2.66 \\
\hline $\mathrm{Mg}^{++}$ & 1.99 \\
\hline $\mathrm{CEC}(\mathrm{Cmol}(+) / \mathrm{kg}$ soil $)$ & 6.97 \\
\hline Extractable P (mg/g) & 6.52 \\
\hline pH (in water 1:2.5) & 5.7 \\
\hline Organic carbon $(\%)$ & 0.79 \\
\hline
\end{tabular}

\section{Animal manures}

The three types of animal manures namely dairy cow, goat, and poultry manure used in this study were collected from the department of Animal Science and Production farm at SUA. Small sub-samples from each manure type were taken for laboratory analyses at SUA in order to determine their nutrient composition. Before analysis, the manure samples were air dried and ground to pass through $2 \mathrm{~mm}$ sieve. The samples were then analysed for total $\mathrm{N}$, total $\mathrm{P}$ and organic carbon following the procedures outlined in the previous section. The results of these analyses are summarised in Table 2.

TABLE 2. Some characteristics of the three types of animal manures

\begin{tabular}{|l|c|c|c|}
\hline \multicolumn{1}{|c|}{ Parameter } & \multicolumn{3}{|c|}{ Animal manure typy } \\
\hline & Dairy cow manure & Goat manure & Poultry manure \\
\hline Organic carbon (\%) & 20.94 & 14.99 & 14.97 \\
\hline Total N (\%) & 1.449 & 1.645 & 1.844 \\
\hline Total P (\%) & 0.119 & 0.208 & 0.526 \\
\hline C:N ratio & $14: 01$ & $9: 01$ & $8: 01$ \\
\hline C:P ratio & $176: 01: 00$ & $72: 01: 00$ & $28: 01: 00$ \\
\hline
\end{tabular}




\section{Pot experiment}

This study was conducted with the objective of comparing the effects of the three animal manures on soil available levels of $\mathrm{N}$ and $\mathrm{P}$, amaranthus shoot dry matter yield and root growth. Four kilogram air dried soil from the field experimental site was weighed into plastic pots and mixed with the animal manures. The treatments were; Control (no manure applied), dairy cow, goat and poultry manure each at three rates namely; $100 \mathrm{~kg} \mathrm{~N} / \mathrm{ha}, 150 \mathrm{~kg} \mathrm{~N} / \mathrm{ha}$ and $170 \mathrm{~kg}$ $\mathrm{N} / \mathrm{ha}$. The treatments were replicated three times in a split plot design with rates of application as main plots and manure types as the subplots. Amaranthus seeds were sown in the pots by broadcasting followed by slight stirring of the soil. Before sowing, the seeds were thoroughly mixed with sand at a ratio of 2:50 (seeds:sand) giving a sowing rate of $3-10 \mathrm{~g} / \mathrm{m}^{2}$. The pots were then watered using distilled water to approximately field capacity. Thinning was done to 10 plants per pot seven days after emergency. Harvesting was done after four weeks of plant growth by cutting the plants $2 \mathrm{~cm}$ above the soil level. The plants were then rinsed of any adhering particles using distilled water and oven dried at $65^{\circ} \mathrm{C}$ to a constant weight for dry matter yield determination.

\section{Soil analysis and root growth determination after harvest}

After plant harvest, a small sub-sample of soil was collected for determination of soil available levels of $\mathrm{N}$ and $\mathrm{P}$. Soil samples were air dried, ground and sieved through a $2 \mathrm{~mm}$ sieve. Available nitrogen was determined by the micro Kjeldahl method as outlined by Okalebo et al. (1993) while available $\mathrm{P}$ was determined by Bray 1 method (Bray and Kurtz, 1945).

Assessment of root growth was done for each treatment by measuring taproot length and determining root dry weight. Intact roots of five randomly selected plants from each pot were used. These were gently washed with running water from watering cans to remove the soil. After rinsing with distilled water, taproot length was directly measured using a ruler while root dry weight was taken after oven drying the roots at $65^{\circ} \mathrm{C}$ to constant weight.

\section{Field experiment}

Field experiment was conducted to compare the effects of the three animal manures on amaranthus shoot dry matter yield, and soil available levels of $\mathrm{N}$ and $\mathrm{P}$ under field conditions. The experiment was conducted over a period of three crop cycles each lasting for one month.
The experimental site was ploughed and harrowed. Plot size was $4.0 \mathrm{~m} \times 1.5 \mathrm{~m}$. The main plots were separated by a $1.5 \mathrm{~m}$ path while the subplots were separated by a $1.0 \mathrm{~m}$ path. The experimental design was similar to that of the pot experiment except that field experiment had four replications. The animal manures were applied by broadcasting followed by incorporation into the soil manually before sowing.

Amaranthus seeds were sown by broadcasting as was in the pot experiment at the rate of $2.0 \mathrm{~kg} / \mathrm{ha}$ as recommended by Tindall (1983). The experimental plots were kept free from weeds throughout the study duration. Plots were irrigated manually using watering cans when necessary. Harvesting was done after four weeks of plant growth for each crop cycle on an area of $1.0 \mathrm{~m} \times 1.0 \mathrm{~m}$ at the centre of each plot. Samples from each treatment were oven dried at $65^{\circ} \mathrm{C}$ to constant weight to obtain shoot dry matter yield. Soil samples were taken after the first and third crop harvests for determination of available levels of $\mathrm{N}$ and $\mathrm{P}$ following procedures outlined by Okalebo et al. (1993).

\section{Statistical analysis}

Data from each experiment were analysed using the MSTATC program. Standard ANOVA procedures were employed according to procedures outlined by Snedcor and Cochran (1993). Duncan's New Multiple Range Test (DNMRT) was used to compare differences between treatment means. Linear correlations for various variables were carried out according to the procedures described by Steel and Torrie (1984).

\section{RESULTS AND DISCUSSION}

\section{Pot experiment}

\section{Effect of animal manures on soil available $N$ and $P$}

Soil available levels of $\mathrm{N}$ and $\mathrm{P}$ after harvesting are presented in Figures 1 and 2. There was a significant $(\mathrm{P}<$ $0.01)$ manure type $X$ manure application rate interaction suggesting variation in the effectiveness of the amendments at different rates of application. Soil available $\mathrm{N}$ and $\mathrm{P}$ significantly $(\mathrm{P}<0.05)$ increased with increasing rate of manure application for each manure type. The highest rate of application ( $170 \mathrm{~kg} \mathrm{~N} / \mathrm{ha}$ ) resulted in highest effect on soil available levels of $\mathrm{N}$ and $\mathrm{P}$ for all manure types. 


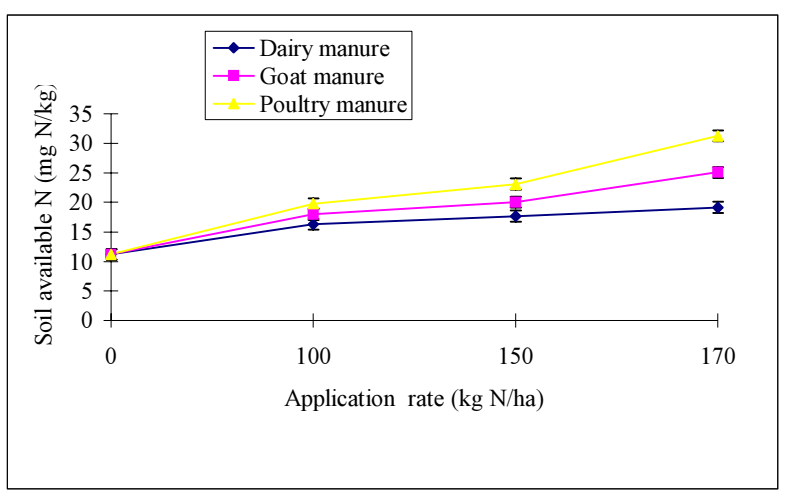

Figure 1. Effect of the animal manures on soil available $\mathrm{N}$

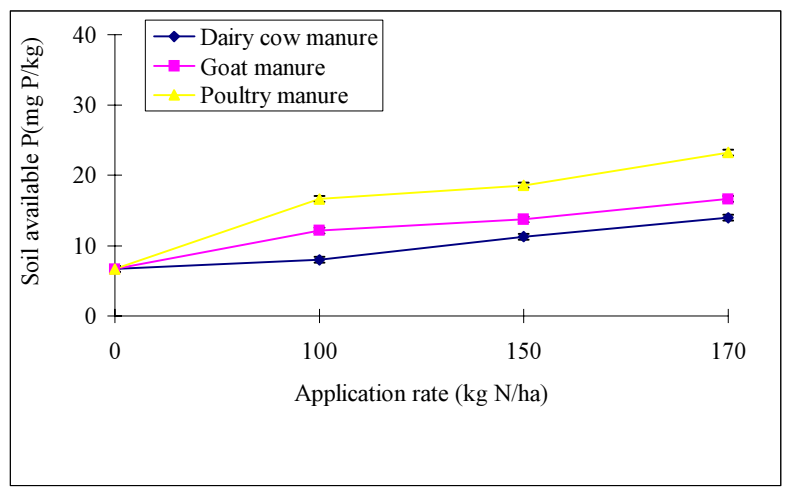

Figure 2. Effect of the animal manures on soil available $P$

The three manure types differed significantly $(\mathrm{P}<0.01)$ in terms of soil available levels of $\mathrm{N}$ and $\mathrm{P}$ at each manure application rate. The trend was; poultry manure $>$ goat manure $>$ dairy cow manure. This trend was expected given the initial differences in total $\mathrm{N}$, total $\mathrm{P}$ and organic carbon contents of the manures (Table 2). Poultry manure had highest values of total $\mathrm{N}$ and total $\mathrm{P}$ and narrowest $\mathrm{C}: \mathrm{N}$ and $\mathrm{C}: \mathrm{P}$ ratios compared to goat and dairy cow manures (Table 2). The increase in soil available levels of $\mathrm{N}$ and $\mathrm{P}$ with application rates of the animal manures could be attributed to increased microbial activities as a result of increased concentration of nutrients. This could have resulted in enhanced decomposition of the organic forms of $\mathrm{N}$ and $\mathrm{P}$, hence increased availability of $\mathrm{N}$ and P. Similar results were reported by Bomke and Lavkulich (1975) and Schegel (1992) who observed that poultry manure had highest effect on soil available levels of $\mathrm{N}$ and $\mathrm{P}$ compared to other animal manures.

\section{Effect of the animal manures on root growth}

Taproot length and root dry weight were significantly influenced by the application of the three animal manure types (Table 3 ). There was a significant manure type $\mathrm{X}$ rate of application interaction $(\mathrm{P}<0.05)$ suggesting that the two root growth parameters were differentially affected by the applications of the manures at different application rates. Irrespective of the manure type, taproot length and root dry weight increased with increasing manure application rate (Table 3 ).

TABLE 3. Effect of the animal manures on amaranth root dry weight

\begin{tabular}{|l|l|l|l|}
\hline \multirow{2}{*}{$\begin{array}{l}\text { Rate } \mathrm{N} / \mathrm{kg}) \\
\text { Control }\end{array}$} & \multirow{2}{*}{$\begin{array}{l}\text { Manure } \\
\text { type }\end{array}$} & $\begin{array}{l}\text { Tap root } \\
\text { length } \\
\text { (cm/plan }\end{array}$ & $\begin{array}{l}\text { Root dry } \\
\text { weight } \\
(\mathrm{mg} / \mathrm{pot})\end{array}$ \\
\hline & & $9.13 \mathrm{~g}$ & $50.7 \mathrm{~g}$ \\
\hline 100 & Poultry & $18.50 \mathrm{~d}$ & $103.0 \mathrm{bc}$ \\
\hline & Goat & $16.0 \mathrm{e}$ & $84.7 \mathrm{de}$ \\
\hline & Dairy & $14.03 \mathrm{f}$ & $67.3 \mathrm{efg}$ \\
\hline & & & \\
\hline 150 & Poultry & $21.1 \mathrm{c}$ & $123.0 \mathrm{~b}$ \\
\hline & Goat & $17.7 \mathrm{~d}$ & $95.0 \mathrm{~cd}$ \\
\hline & Dairy & $15.7 \mathrm{e}$ & $73.0 \mathrm{ef}$ \\
\hline & & & \\
\hline 170 & Poultry & $29.6 \mathrm{a}$ & $157.0 \mathrm{a}$ \\
\hline & Goat & $24.4 \mathrm{~b}$ & $117.7 \mathrm{~b}$ \\
\hline \hline & Dairy & $17.7 \mathrm{~d}$ & $93.7 \mathrm{~cd}$ \\
\hline \hline
\end{tabular}

Means followed by the same letter(s) within the columns do not differ significantly at $P<0.05$ according to DNMRT.

The effect of the three manure types on the two variables differed significantly except for the lowest rate of application (100 kg N/ha), where there was no significant difference. The trend of the effects of the manure types on these two variables was poultry manure $>$ goat manure $>$ dairy cow manure. These results are consistent with those of available levels of $\mathrm{N}$ and $\mathrm{P}$ (Figures 1 and 2) suggesting that the observed increase in root growth was influenced by the increased levels of $\mathrm{N}$ and $\mathrm{P}$ following applications of the animal manures. Similar results were reported by Wright et al. (1995), who observed that maximum root growth and rooting depth of barley crop were higher in treatments, which received animal manures relative to where manure was not applied. 


\section{Effect of the animal manures on amaranthus yield}

Amaranthus shoot dry matter yield results are shown in Figure 3 . Yields were significantly $(\mathrm{P}<0.05)$ increased by the applications of the three animal manures and increased with increasing application rate. Comparison of the effects of the different manures indicated that poultry manure resulted in significantly higher yields relative to goat and dairy cow manure. Generally, the trend was; poultry manure $>$ goat manure $>$ dairy cow manure.

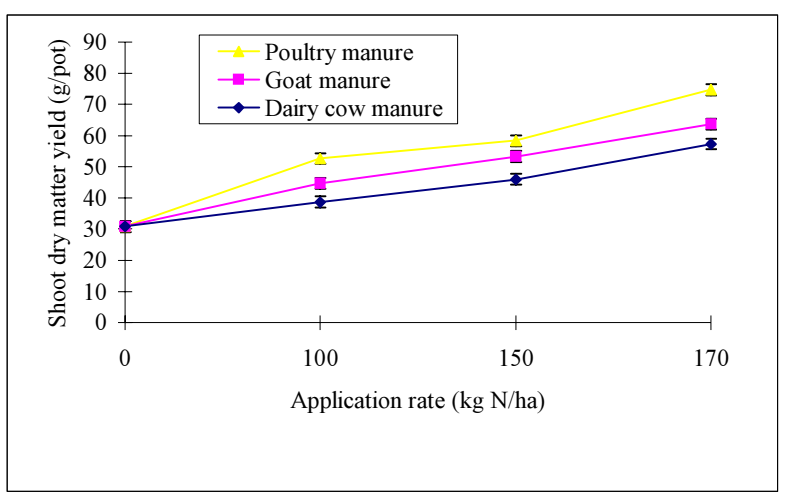

FIGURE 3: Effect of the animal manures on amaranthus shoot dry matter yield

These results are consistent with those of soil available $\mathrm{N}$ and $\mathrm{P}$ (Figures 1 and 2) and root growth (Table 3) which indicated that application of poultry manure resulted in highest levels of soil available $\mathrm{N}$ and $\mathrm{P}$ compared to the other two manures. The results therefore suggest that the observed response was largely due to increased availability of $\mathrm{N}$ and $\mathrm{P}$ and consequently enhanced root growth. This is further supported by the correlation coefficients whereby shoot dry matter yield was highly and positively correlated to soil available levels of $\mathrm{N}$ and $\mathrm{P}$, tap root length and root weight (Table 4). The results are in agreement with those reported by Massomo and Rweyemamu (1989) who observed significant effects on yield of common beans following application of poultry manure.

TABLE 4. Correlation of some selected parameters

\begin{tabular}{|c|c|c|c|c|}
\hline $\begin{array}{l}\text { Shoot dry } \\
\text { matter yield }\end{array}$ & \multicolumn{2}{|c|}{$\begin{array}{c}\text { Soil available } \\
\text { levels }\end{array}$} & $\begin{array}{c}\text { Taproot } \\
\text { length }\end{array}$ & $\begin{array}{c}\text { Root dry } \\
\text { weight }\end{array}$ \\
\hline & $\mathrm{N}$ & $\mathrm{P}$ & & \\
\hline Correlation & 0.9 & 0.93 & 0.89 & 0.86 \\
\hline $\begin{array}{l}\text { Student's T } \\
\text { value }\end{array}$ & 11.77 & 14.93 & 11.36 & 9.96 \\
\hline Probability & $0.00 * *$ & $0.00 * *$ & $0.00 * *$ & $0.00 * *$ \\
\hline
\end{tabular}

$* *=$ Highly significant at $P<0.01$.

\section{FIELDEXPERIMENT}

\section{Effect of animal manures on soil available levels of $\mathbf{N}$ and $\mathbf{P}$}

Results of soil available levels of $\mathrm{N}$ and $\mathrm{P}$ after harvesting (first and third crop cycles) are presented in Figures 4, 5, 6 and 7. There was a significant $(P<0.01)$ manure type $X$ application rate interaction during the first and third crop cycles suggesting variation in effectiveness of the three manures at different rates of application. Irrespective of the type of animal manure, soil available levels of $\mathrm{N}$ and $\mathrm{P}$ significantly $(\mathrm{P}<0.01)$ increased with rates of application during both first and third crop cycles. As was in the pot experiment, the highest rate of application (170 kg N/ha) resulted in the highest effect for all manure types and crop cycles. The trend was poultry manure $>$ goat manure $>$ dairy manure. The observed trend was consistent with the differences in the three manures with respect to total $\mathrm{N}$, total $\mathrm{P}$ and organic carbon.

The levels of available $\mathrm{N}$ and $\mathrm{P}$ after the third crop cycle were significantly higher $(\mathrm{P}<0.01)$ for all manure types compared to those of the first crop cycle. Irrespective of the shorter experimental duration (three months) this trend was expected since the decomposing micro flora, require substantial time to act on organic materials. Klausner and Bouldin (1973) observed that organic $\mathrm{N}$ and $\mathrm{P}$ mineralizes over a period of time which eventually decreases with increasing time after the initial application.

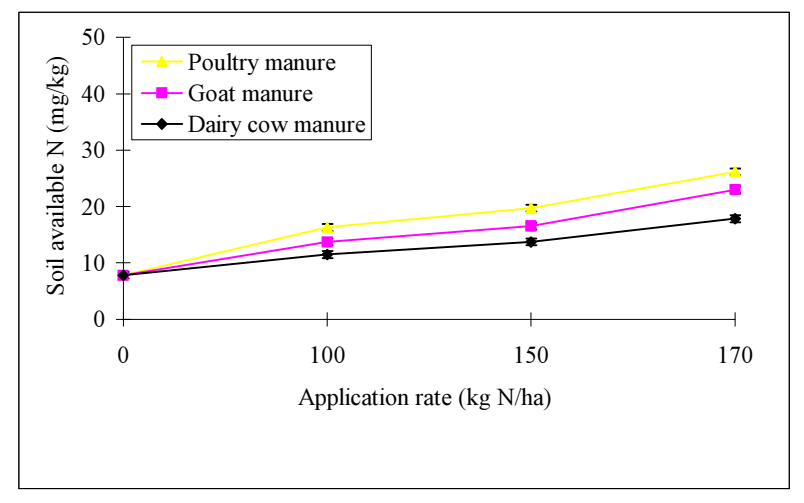

FIGURE 4. Effect of the animal manures on soil available $\mathrm{N}$ during first crop harvest 


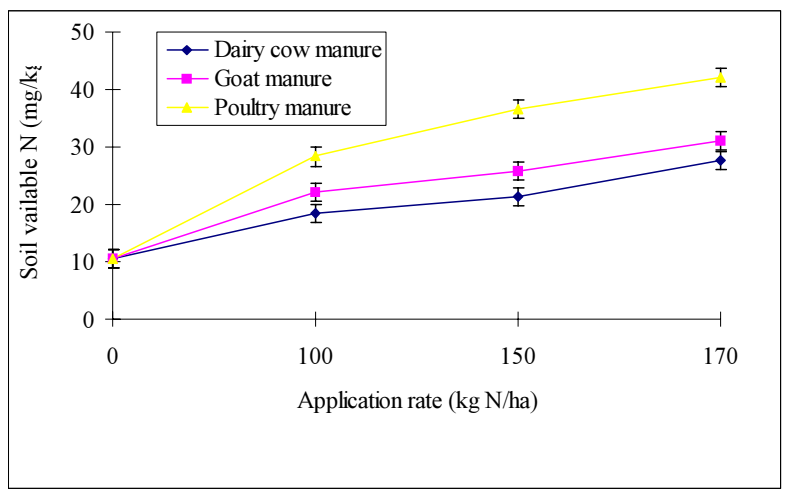

FIGURE 5: Effect of the animal manures on soil available $\mathrm{N}$ during the third crop harvest

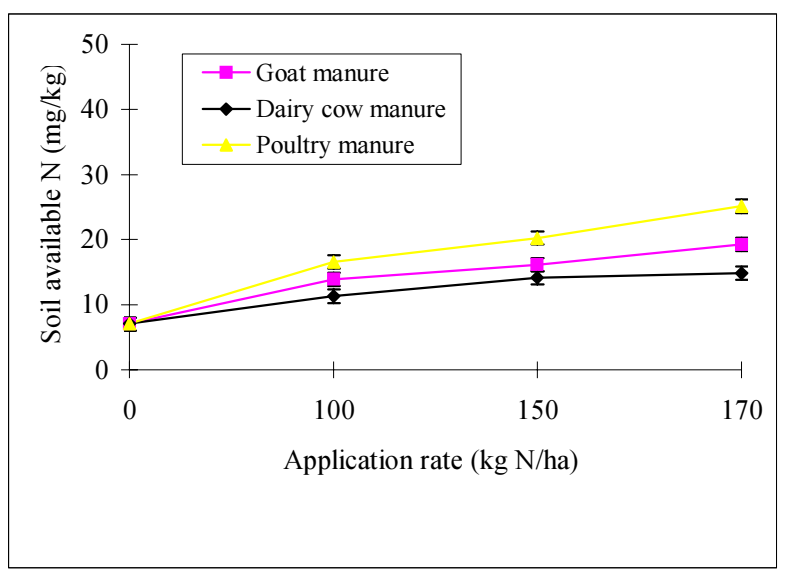

FIGURE 6: Effect of the animal manures on soil available $P$ during first crop harvest

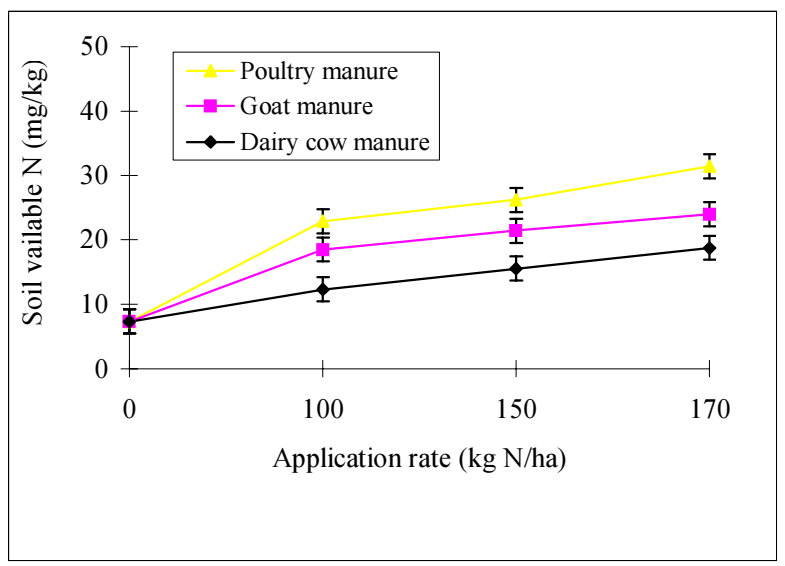

FIGURE 7. Effect of the animal manures on soil available $\mathrm{P}$ during the third crop harvest

\section{Effect of animal manures on dry matter yield}

Amaranths shoot dry matter yields for the first, second and third harvests are presented in Figure 8, 9 and 10 respectively. The yields increased over successive harvests during the three months of the experiment. Highest yield was obtained during the third harvest and lowest yields during the first harvest. This was consistent with the results of the soil available $\mathrm{N}$ and $\mathrm{P}$ (Figures 5-7) which indicate that the highest levels of available $\mathrm{N}$ and $\mathrm{P}$ were obtained after the third crop harvest. This suggests that the observed responses were largely due to increased levels of $\mathrm{N}$ and $\mathrm{P}$ following increased mineralization of organic forms of $\mathrm{N}$ and $\mathrm{P}$ with time.

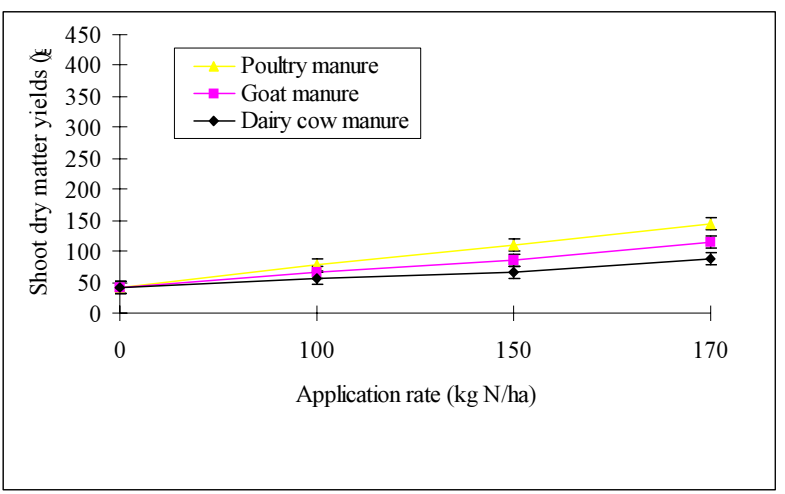

Figure 8. Effect of the animal manures on amaranthus dry matter yield at the first crop harvest.

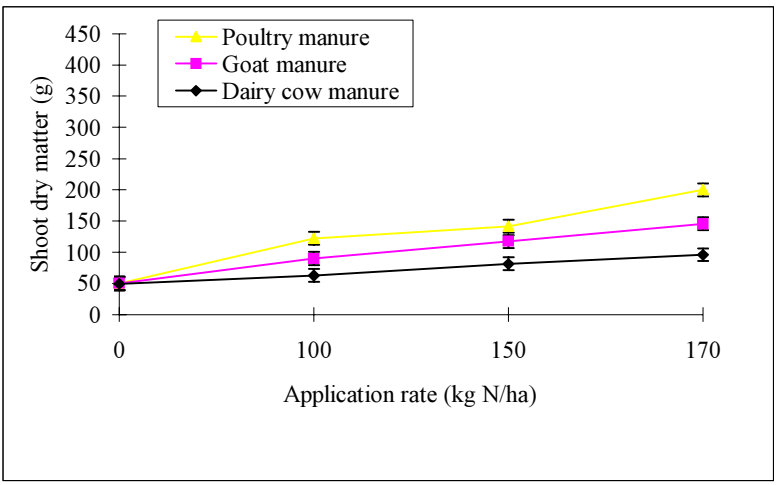

Figure 9. Effect of the animal manures on amaranthus shoot dry matter yield at the second crop harvest 


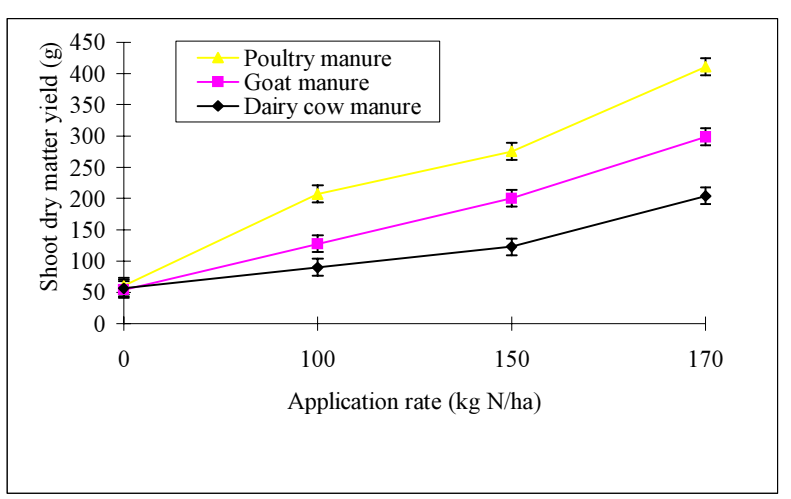

FIGURE 10. Effect of the animal manures on amaranthus shoot dry matter yield at the third crop harvest

There was a significant $(\mathrm{P}<0.01)$ manure type and application rate interaction for all harvests indicating differential effects of the three manures at different rates of application. All the animal manures significantly $(\mathrm{P}<$ 0.01 ) increased amaranthus yields and the responses increased with increasing rate of application in all three crop harvests. Comparison of the three types of manures indicates that for all three crop harvests poultry manure gave the highest response followed by goat and dairy cow manures. This could possibly be due to higher content of total $\mathrm{N}$ and $\mathrm{P}$ in poultry manure compared to the other two manure types. Also, poultry manure contains easily decomposable materials most of which are in the form of urea and uric acid. The above observations are supported by the correlation coefficients, which show that shoot dry matter yield was highly and positively correlated to soil available levels of $\mathrm{N}$ in the first and third crop cycles (Table 6).Results of the field experiment confirm those of the pot experiment. In both experiments the highest responses were obtained from poultry manure treatments while dry matter yield was highly related to soil availability of $\mathrm{N}$ and $\mathrm{P}$.

TABLE 6: Correlations of some selected parameters in the field experiment

\begin{tabular}{|c|c|c|c|c|}
\hline \multirow{3}{*}{$\begin{array}{l}\text { DM } \\
\text { y ield: }\end{array}$} & \multicolumn{4}{|c|}{ Soil available $\mathrm{N}$ and $\mathrm{P}$} \\
\hline & \multicolumn{2}{|l|}{$\mathrm{N}$} & \multicolumn{2}{|c|}{$\mathrm{P}$} \\
\hline & 1 & 3 & 1 & 3 \\
\hline Correlation & 0.88 & 0.94 & 0.87 & 0.94 \\
\hline Student's T value & 8.41 & 16.47 & 10.4 & 16.18 \\
\hline Probability & $0.00 * *$ & $0.00 * *$ & $0.00 * *$ & $0.00 * *$ \\
\hline
\end{tabular}

$1=$ First crop cycle $3=$ Third crop cycle

$* *=$ Highly significant at $P<0.01$
Net available $\mathbf{N}$ and $\mathbf{P}$ and implications on manure recommendations

Tables 7 shows net available values of $\mathrm{N}$ and $\mathrm{P}$ after the third crop harvest. Recommended rates of $\mathrm{N}$ and $\mathrm{P}$ for Southern highlands of Tanzania for most field crops are $40-50 \mathrm{~kg} \mathrm{~N} / \mathrm{ha}$ and $20 \mathrm{~kg} \mathrm{P} / \mathrm{ha}$ (MOAC, 1996). Based on this and at application rate of $170 \mathrm{~kg} \mathrm{~N} / \mathrm{ha}$, applications of poultry, goat and dairy cow manures at the rates of 5.8 tons/ha, 9.8 tons/ha and 13 tons/ha respectively will meet the recommendation of $40 \mathrm{~kg} \mathrm{~N} / \mathrm{ha}$. The above rates of poultry, goat and dairy cow manures which are based on $\mathrm{N}$ requirement will also provide $30 \mathrm{~kg} \mathrm{P} / \mathrm{ha}, 31.6 \mathrm{~kg} \mathrm{P} / \mathrm{ha}$ and $26.8 \mathrm{~kg} \mathrm{P} / \mathrm{ha}$, respectively. These will suffice the $\mathrm{P}$ recommendation for the region without the need for supplementation with inorganic $\mathrm{P}$ sources.

Table 5: Net soil available $\mathrm{N}$ and $\mathrm{P}$ after the third crop harvest ( $\mathrm{mg} / \mathrm{kg}$ soil)

\begin{tabular}{|c|l|c|c|}
\hline Rate & Manure & Net N & Net P \\
\hline 100 & Poultry & 18.1 & 15.6 \\
\hline & Goat & 11.9 & 6.7 \\
\hline & Dairy cow & 8.3 & 4.9 \\
\hline 150 & Poultry & 26.4 & 18.9 \\
\hline & Goat & 15.6 & 14.1 \\
\hline & Dairy cow & 11.2 & 8.2 \\
\hline 170 & Poultry & 31.2 & 24.1 \\
\hline & Goat & 20.8 & 16.7 \\
\hline & Dairy cow & 17.5 & 11.4 \\
\hline
\end{tabular}

\section{CONCLUSIONSAND RECOMMENDATIONS}

The objective of this study was to comparatively evaluate the effects of poultry, goat and dairy cow manures on selected soil chemical properties, amaranths yield and root growth.

Results of the pot experiment indicated that applications of the three animal manures significantly increased the chemical soil properties evaluated. Irrespective of the manure type, soil available levels of $\mathrm{N}$ and $\mathrm{P}$ increased with increasing rates of application. The results also revealed variations among the three manures and the trend was: poultry manure $>$ goat manure $>$ dairy cow manure. Similar trends were observed for other attributes observed namely, shoot dry matter yield, taproot length and root dry weight. These responses could largely be due to the initial differences in total $\mathrm{N}$, total $\mathrm{P}$ and organic carbon of the three manures. Poultry manure had the highest levels of total $\mathrm{N}$, total $\mathrm{P}$ and narrowest ratios of $\mathrm{C} / \mathrm{N}$ and $\mathrm{C} / \mathrm{P}$, 
suggesting superior mineralization of organic forms of $\mathrm{N}$ and $\mathrm{P}$ compared to goat and dairy cow manures. Amaranthus dry matter yield was highly and positively correlated to available levels of $\mathrm{N}$ and $\mathrm{P}$, tap root length and root weight, indicating that these responses were largely due to availability and uptake of $\mathrm{N}$ and $\mathrm{P}$. Generally, results of the field experiment confirmed those of the pot experiment. Soil available levels of $\mathrm{N}$ and $\mathrm{P}$ after the third crop harvest were higher than those of the first crop cycle indicating that mineralization of $\mathrm{N}$ and $\mathrm{P}$ increased with time after the initial application of the organic amendments. As it was for the pot experiment, highest responses of the evaluated parameters were obtained from poultry manure. Applications of the three manures could therefore immensely improve fertility of this soil and others with similar properties. Given its superior responses, poultry manure could be a very attractive fertilizer alternative particularly for annual crops with short growth cycle such as amaranthus. Results of this study should however, be confirmed under different field conditions and for longer experimental duration

\section{REFERENCES.}

Bray, R.H. and Kurtz L.T. 1945. Determination of total organic and available forms of phosphorus in soils. Soil Science. 39:39-45.

Bremner, J.M. and Mulvaney C.S. 1982. Nitrogen total. In: Methods of soil analysis Part 2.2 $2^{\text {nd }}$ Edition (eds. A.L. Page, R.H. Miller and D.R. Kenney). ASA. ASSS. Monograph No. 9 Madison. USA. pp. $595-$ 624

Bomke, A.A. and Lavkulich L.M. 1975. Composition of poultry manure and effect of heavy application on soil chemical properties and plant nutrition. British Colombia, Canada. In: Managing Livestock Wastes. pp. 611-617.

Gabriel, B.L.M. 1998. Utilization and management of animal manures for crop production. The case of Urban Morogoro and Kilosa Districts. BSc. (Agriculture) Special Project. Sokoine University of Agriculture, Morogoro. Tanzania.

Hauck, F.W. 1981. Organic recycling to improve soil productivity. In: Organic materials and Soil Productivity. FAO. Soil Bulletin. No. 45. FAO. Rome. pp. 15-17.

Juo, A. S.R. (Ed.). 1978. Selected Methods for soil and Plant Analysis. Manual Series No. 1, $2^{\text {nd }}$ Ed. IITA. Ibadan, Nigeria.
Kimbi, GG., V. Rutachokizibwa, N.M. Mollel, T.E.Simalenga, M.S. Ngetti and Biswalo P.L. 1992. Identification of SUA-TU Linkage Project needs assessment: A preliminary survey. Report submitted to SUA-TU Linkage Project. Institute of Continuing Education, Sokoine University of Agriculture.

Klausner, S. and Bouldin D. 1973. Management of animal manures: Decomposition Series. Cooperative Extension Series. 3-8.

Massomo, S.M.S. and C.L. Rweyemamu. 1989. Evaluation of the effects of cattle and poultry manure in combination with inorganic $\mathrm{N}$ fertilizer on seed yield, yield components and seed quality of common bean (P. vulgaris L.) grown in different plant stands per hill. In: Bean Research. Maeda and Nchimbi (eds.) Vol. 4: 88-98.

McLean, E.O. 1982. Soil $\mathrm{pH}$ and Lime requirements. Agronomy 9: 199-223.

MOAC. 1996. Plant nutrition programmes in Tanzania. Synthesis of project prominent findings and recommendations. Vol. 1 Agronomic results. TanzaniaTechnical Reports 35pp.

Okalebo, J.R., K.W. Gathua, and P.L. Woomer 1993. Laboratory methods of soil and plant analysis. A working manual. KARI. and ROST.

Schlegel, A.J. 1992. Effect of composted manure on soil chemical properties and nitrogen use by grain sorghum. Journal of Production Agriculture. 5:153157.

Snedcor, G.W. and Cochran W.G. 1993. Statistical Methods. $8^{\text {th }}$ Ed. Iowa State University Press/Ames. 503 pp.

Steel, R.G.D. and Torrie J.H. 1984. Principles and procedures of statistics. In: $A$ biometrical approach. McGraw Hill Book Company. New York.

Tindall, H.D. 1983. Vegetables in the Tropics. Macmillan Education Ltd. London. pp. 36-48.

Thomas, G.W.1982. Exchangeable cations. In: Methods of soil analysis. Part 2. $2^{\text {nd }}$ edition. (Eds. A.L. Page, R.H. Miller and D.R Keeney) ASA. SSSA. Monograph. No.9. Madison. Wisconsin, USA. pp. 159-165.

Wilde, S.A., R.B. Corey, and J.G. Iyer. 1979. Soil and plant analysis for tree culture. Oxford and IBH Publishing Co. New Delhi. pp. 224.

Wright, R. J., J.L. Hern, V.C. Balingar and O.L. Bennet. 1995. The effects of surfaceapplied soil amendments on barley root growth in an acid sub soil. Communications in Soil Science and Plant Analysis. 16:179-192. 